\title{
EKSPERIMENTALNO ISTRAŽIVANJE MEHANIČKIH SVOJSTAVA ZIĐA OD PUNE OPEKE
}

\author{
Krešimir Mirosavljević \\ Sveučilište J. J. Strossmayera u Osijeku, Građevinski fakultet Osijek, dipl.ing.građ. \\ Mirjana Bošnjak-Klečina \\ Sveučilište J. J. Strossmayera u Osijeku, Građevinski fakultet Osijek, doc.dr.sc., dipl.ing.građ. \\ Davorin Penava \\ Sveučilište J. J. Strossmayera u Osijeku, Građevinski fakultet Osijek, mr.sc., dipl.ing.građ.
}

Sažetak: Opisuju se rezultati ispitivanja mehaničkih svojstava nearmiranih elemenata ziđa, zidnih elemenata i morta. $\mathrm{Na}$ nearmiranim elementima ziđa utvrđena je tlačna i posmična čvrstoća, te je mjerenjem deformacija određen sekantni modul elastičnosti. Rezultati eksperimentalnog istraživanja tlačne čvrstoće ziđa uspoređeni su s pojednostavljenim analitičkim izrazima dostupnim u literaturi. Utvrđena su odstupanja u srednjim vrijednostima izmjera zidnih elemenata koja je objavio proizvođač, u odnosu na dopuštene normom HRN EN 771-1:2002 [3]. Ispitivanja su provedena prema smjernicama norme prEN 1996-1-1 [2].

Ključne riječi: ispitivanje, čvrstoća, tlak, posmik, element ziđa, opeka, mort

\section{EXPERIMENTAL STUDY OF MECHANICAL PROPERTIES OF FULL BRICK MASONRY}

Abstract: In this paper a set of mechanical properties of masonry prisms, masonry units and mortar is given. Compression and shear strength, and additionaly based on measured strains the secant elastic modulus are determined for unreinforced masonry prisms. Results of experimental investigations have been compared with analytical expressions available in the literature. By analyzing masonry units through HRN EN 771-1:2002 [3] normative, inadmissable deviations in unit dimensions are noticed. All tests have been done by following the guidelines from prEN 1996-1-1 [2] normative.

Key words: experiment, strength, compression, shear, masonry prism, brick, mortar 


\section{Uvod}

U radu su prikazani rezultati ispitivanja tlačne i posmične čvrstoće nearmiranih elemenata ziđa, tlačne čvrstoće zidnih elemenata te tlačne i vlačne čvrstoće morta. Na osnovi mjerenih deformacija tijekom ispitivanja na tlak, određena je srednja vrijednost sekantnog modula elastičnosti ziđa u smjeru opterećenja. Rezultati eksperimentalnog istraživanja tlačne čvrstoće ziđa uspoređeni su s pojednostavljenim analitičkim izrazima za proračun tlačne čvrstoće ziđa koji uzimaju u obzir tlačnu čvrstoću zidnih elemenata i morta s različitim postotkom doprinosa. Ispitivanje zidnih elemenata provedeno je u skladu s normama HRN EN 771-1:2002 [3] i HRN EN 772-1:200 [4], ispitivanje morta u skladu s normom HRN EN 1015-11:2000 [5], te ispitivanje tlačne i posmične čvrstoće ziđa u skladu s normama HRN EN 1052-1:2004 [6] i HRN EN 1052-2:2004 [7].

\section{Zidni elementi}

Odabrano je 6 zidnih elemenata (puna opeka) standardnih izmjera $I_{u} \times w_{u} \times h_{u}=250 \times 120 \times 65 \mathrm{~mm}$ prema slici 1 , gdje je $I_{u}$ duljina, $w_{u}$ širina, te $h_{u}$ visina zidnog elementa. Zidni elementi se, ovisno o udjelu i orijentaciji šupljina nakon ugradnje (smjer opterećenja), svrstavaju u skupinu 1, 2, 3 ili 4. Puna opeka ne sadržava oblikovane praznine cijelom visinom niti samo jednim dijelom svog volumena, zbog čega se u skladu s normom prEN 1996-1-1 [2] svrstava u grupu 1 zidnih elemenata.

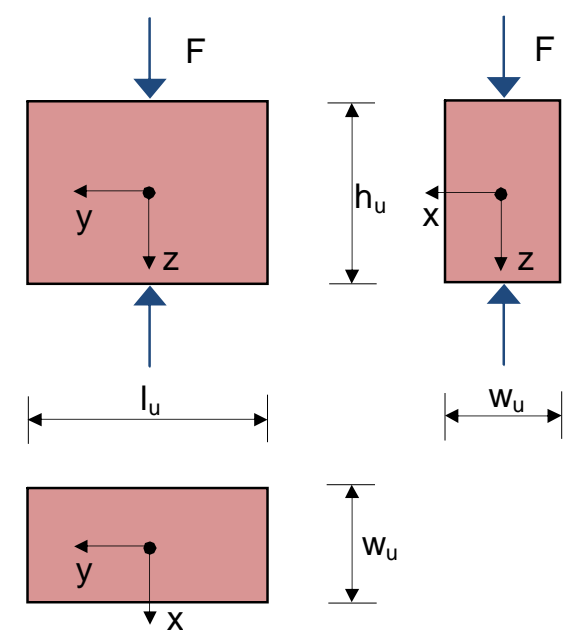

Slika 1 - Zidni element s osnovnim izmjerama i smjerom opterećenja

\subsection{Izmjere i površine}

Glineni zidni elementi podložni su odstupanjima u izmjerama te se stoga, u skladu s normom HRN EN 771-1:2002 [3], svrstavaju u razrede. U skladu s tim, zidnim elementima su utvrđene stvarne izmjere i prikazane su u tablici 1. 


\section{Tablica 1 - Stvarne vrijednosti izmjera ispitnih uzoraka}

\begin{tabular}{|c|c|c|c|}
\hline $\begin{array}{c}\text { Redni broj uzorka } \\
(\mathrm{n})\end{array}$ & $\mathrm{lu}_{\mathrm{u}}(\mathrm{mm})$ & $\mathrm{Wu}_{\mathrm{u}}(\mathrm{mm})$ & $\mathrm{h}_{\mathrm{u}}(\mathrm{mm})$ \\
\hline 1. & 249 & 123 & 61 \\
\hline 2. & 250 & 124 & 60 \\
\hline 3. & 250 & 124 & 62 \\
\hline 4. & 250 & 125 & 60 \\
\hline 5. & 250 & 121 & 61 \\
\hline 6. & 250 & 125 & 62 \\
\hline Srednja vrijednost & 250 & 124 & 61 \\
\hline Odstupanje & 0 & +4 & -4 \\
\hline
\end{tabular}

Srednje vrijednosti odstupanja od standardnih izmjera zidnog elementa Tm objavio je proizvođač. Objavljivanje razlike između najveće i najmanje određene izmjere na pojedinom elementu $R m$, prema normi HRN EN 771-1:2002 [3], proizvođač nije objavio. U tablici 2, u skladu s normom HRN EN 771-1:2002 [3], prikazane su vrijednosti u odstupanjima srednjih vrijednosti izmjera prema razredima u usporedbi s objavljenim vrijednostima. Prema danim podatcima, zidni elementi ne pripadaju razredu $T 1$ niti razredu T2, jer je odstupanje u visini elementa veće od izmjerenih stvarnih vrijednosti.

\section{Tablica 2 - Srednje vrijednosti odstupanja izmjera}

\begin{tabular}{|l|c|c|c|}
\hline & $l_{u}(\mathrm{~mm})$ & $W_{u}(\mathrm{~mm})$ & $h_{u}(\mathrm{~mm})$ \\
\hline T1 & \pm 6 & \pm 4 & \pm 1 \\
\hline T2 & \pm 4 & \pm 3 & \pm 1 \\
\hline Tm & \pm 10 & \pm 5 & \pm 4 \\
\hline
\end{tabular}

\subsection{Tlačna čvrstoća}

Proizvođač objavljuje (deklarira) tlačnu čvrstoću zidnih elemenata kao srednju i/lii karakterističnu vrijednost, najčešće samo u smjeru okomitom na naliježuću površinu. Objavljena vrijednost tlačne čvrstoće usvojenog zidnog elementa je srednja vrijednost i iznosi $f_{b, 0}=20 \mathrm{~N} / \mathrm{mm}^{2}$. Pri projektiranju zidanih konstrukcija primjenjuje se normalizirana srednja vrijednost tlačne čvrstoće $f_{b}$ koja predstavlja istovjetnu tlačnu čvrstoću zidnog elementa izmjera $b_{u} \times h_{u}=100 \times 100 \mathrm{~mm}$ sušenog na zraku, čime proračun postaje neovisan o obliku i izmjerama zidnog elementa pri konačnoj ugradnji.

Normom HRN EN 772-1:2004 [4] propisana je metoda ispitivanja tlačne čvrstoće zidnih elemenata. U skladu S tim, na ispitnim uzorcima izveden je izravnavajući sloj cementnog morta M30. Ispitni uzorci su bili njegovani pod vlažnim folijama. Prije ispitivanja proveli su najmanje 15 sati uronjeni u vodu na temperaturi $20^{\circ} \mathrm{C}$, nakon čega su izvađeni iz vode i ostavljeni da se osuše u trajanju od 20 min. Rezultati ispitivanja tlačne čvrstoće ispitnih uzoraka dani su u tablici 3. 
Tablica 3 - Rezultati ispitivanja tlačne čvrstoće uzoraka pune opeke

\begin{tabular}{|c|c|c|c|c|}
\hline $\begin{array}{l}\text { Redni broj uzorka } \\
\text { (n) }\end{array}$ & $\begin{array}{c}\text { Tlačna čvrstoća pojedinog } \\
\text { uzorka } \\
f_{m c}\left(\mathrm{~N} / \mathrm{mm}^{2}\right)\end{array}$ & $\begin{array}{l}\text { Srednja vrijednost } \\
f_{\mathrm{m} c, \mathrm{sr}}\left(\mathrm{N} / \mathrm{mm}^{2}\right)\end{array}$ & $\begin{array}{c}\text { Koeficijent varijacije } \\
\qquad(\%)\end{array}$ & $\begin{array}{c}\text { Normal. tlačna } \\
\text { čvrstoća } \\
\mathrm{fb}_{\mathrm{b}}\left(\mathrm{N} / \mathrm{mm}^{2}\right)\end{array}$ \\
\hline 1. & 44,6 & \multirow{6}{*}{42,2} & \multirow{6}{*}{10,9} & \multirow{6}{*}{40,0} \\
\hline 2. & 50,2 & & & \\
\hline 3. & 41,2 & & & \\
\hline 4. & 38,2 & & & \\
\hline 5. & 40,7 & & & \\
\hline 6. & 38,2 & & & \\
\hline
\end{tabular}

Normalizirana srednja tlačna čvrstoća zidnog elementa u tabilici 3, a prema normi HRN EN 772-1:2004 [4], dobije se primjenom izraza

$$
f_{b}=1,280 f_{m}=40 \mathrm{Nmm}^{2}
$$

gdje je 1,2 vrijednost faktora ovisnog o uvjetima njegovanja uzoraka, a $\delta=0,79$ faktor oblika. Faktor oblika za dani zidni element određen je primjenom linearne interpolacije u skladu s tablicom A.1 norme HRN EN 772-1:2004 [4]. Vrijednost normalizirane srednje tlačne čvrstoće zidnog elementa, dobivena primjenom vrijednosti čvrstoće zidnog elementa koju je objavio proizvođač, iznosi $f_{b d}=19 \mathrm{~N} / \mathrm{mm}^{2}$.

\section{Mort}

Za izvedbu ziđa od pune opeke primijenjen je mort opće namjene, razreda $M 5$, s volumskim omjerom cementa, građevnog vapna i pijeska 1:1:5 za izvedbu elemenata ziđa, te cementni mort razreda $M 30$, s volumskim omjerom cementa i pijeska 1:5, kao donji i gornji izravnavajući sloj zidnih elemenata. U skladu s normom HRN EN 101511:2000 [5] određena je tlačna čvrstoća morta iz dvije polovine prizmi (slika 2) izmjera $1 \times b \times d=160 \times 40 \times 40 \mathrm{~mm}$, gdje je I duljina, $b$ širina te $d$ visina prizme, prethodno ispitanih na savijanje.

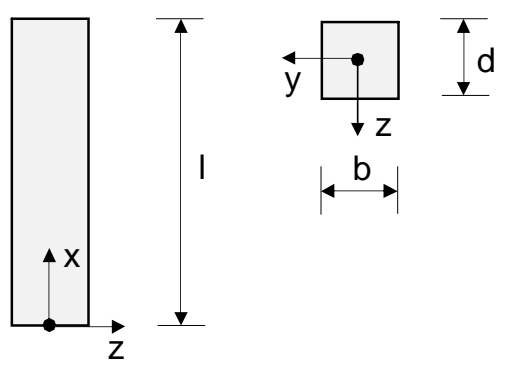

Slika 2 - Prizma morta s osnovnim izmjerama 
Prizme morta izvedene su u metalnim kalupima, zatim su 3 dana njegovane unutar polietilenske folije, te su nakon toga uskladištene u skladu s uvjetima podvodne njege. Rezultati ispitivanja prizmi morta nakon 28 dana prikazani su u tablicama 4 i 5.

S obzirom da je kod morta za izvedbu ziđa dobivena srednja vrijednost tlačne čvrstoće $5,1 \mathrm{~N} / \mathrm{mm}^{2}$, mort pripada razredu M5. Kod drugog morta dobivena je srednja vrijednost tlačne čvrstoće $39,2 \mathrm{~N} / \mathrm{mm}^{2}$ pa mort pripada razredu M30. (U skladu s normom HRN EN 1052-2:2004 [6], srednja vrijednost tlačne čvrstoće morta pripada razredu M5 kad je 5,0 $\leq f_{m, s r}<7,5$. Ukoliko je 30,0 $\leq f_{m, s r}<40,0$, mort pripada razredu M30.)

Tablica 4 - Rezultati ispitivanja čvrstoće morta M5 na savijanje i tlak

\begin{tabular}{|c|c|c|c|c|}
\hline \multirow{2}{*}{$\begin{array}{l}\text { Redni broj uzorka } \\
\text { (n) }\end{array}$} & \multirow{2}{*}{$\begin{array}{c}\text { Vlačna čvrstoća morta } \\
f_{m t}\left(\mathrm{~N} / \mathrm{mm}^{2}\right)\end{array}$} & \multirow{2}{*}{$\begin{array}{c}\text { Tlačna čvrstoća morta } \\
f_{m}\left(\mathrm{~N} / \mathrm{mm}^{2}\right)\end{array}$} & \multicolumn{2}{|c|}{ Srednja vrijednost tlačne i vlačne čvrstoće morta } \\
\hline & & & $\mathrm{f}_{\mathrm{m}, \mathrm{sr}}\left(\mathrm{N} / \mathrm{mm}^{2}\right)$ & $\mathrm{f}_{\mathrm{mt}, \mathrm{sr}}\left(\mathrm{N} / \mathrm{mm}^{2}\right)$ \\
\hline \multirow{2}{*}{1.} & \multirow{2}{*}{0,8} & 5,56 & \multirow{6}{*}{5,1} & \multirow{6}{*}{0,7} \\
\hline & & 5,50 & & \\
\hline \multirow{2}{*}{2.} & \multirow{2}{*}{0,7} & 4,75 & & \\
\hline & & 4,88 & & \\
\hline \multirow{2}{*}{3.} & \multirow{2}{*}{0,7} & 5,00 & & \\
\hline & & 5,00 & & \\
\hline
\end{tabular}

Tablica 5 - Rezultati ispitivanja čvrstoće morta M30 na savijanje i tlak

\begin{tabular}{|c|c|c|c|c|}
\hline \multirow{2}{*}{$\begin{array}{l}\text { Redni broj uzorka } \\
\text { (n) }\end{array}$} & \multirow{2}{*}{$\begin{array}{l}\text { Vlačna čvrstoća morta } \\
f_{\mathrm{mt}}\left(\mathrm{N} / \mathrm{mm}^{2}\right)\end{array}$} & \multirow{2}{*}{$\begin{array}{c}\text { Tlačna čvrstoća morta } \\
f_{m}\left(\mathrm{~N} / \mathrm{mm}^{2}\right)\end{array}$} & \multicolumn{2}{|c|}{ Srednja vrijednost tlačne i vlačne čvrstoće morta } \\
\hline & & & $\mathrm{f}_{\mathrm{m}, \mathrm{sr}}\left(\mathrm{N} / \mathrm{mm}^{2}\right)$ & $f_{\mathrm{mtsr}}\left(\mathrm{N} / \mathrm{mm}^{2}\right)$ \\
\hline \multirow{2}{*}{1.} & \multirow{2}{*}{8,1} & 36,88 & \multirow{6}{*}{39,2} & \multirow{6}{*}{8,0} \\
\hline & & 48,13 & & \\
\hline \multirow{2}{*}{2.} & \multirow{2}{*}{7,3} & 36,88 & & \\
\hline & & 36,88 & & \\
\hline \multirow{2}{*}{3.} & \multirow{2}{*}{8,5} & 41,25 & & \\
\hline & & 35,00 & & \\
\hline
\end{tabular}

\section{$4 \quad$ Karakteristična tlačna čvrstoća ziđa i modul elastičnosti}

U skladu s normom prEN 1996-1-1 [2] karakteristična tlačna čvrstoća ziđa određuje se primjenom empirijskog izraza koji uzima u obzir različiti postotak doprinosa tlačne čvrstoće zidnih elemenata i morta, ovisno o grupi zidnog elementa i vrsti morta ili, u skladu s normom HRN EN 1052-2:2004 [6], eksperimentalnim istraživanjem na elementima ziđa. Preporuka je koristiti podatke dobivene eksperimentalnim istraživanjima. 


\subsection{Eksperimentalni pristup}

Nearmirani elementi ziđa izmjera $l_{s} \times t_{s} \times h_{s}=510 \times 120 \times 385 \mathrm{~mm}$, izvedeni su od punih opeka normalizirane srednje tlačne čvrstoće $f_{b}=40,0 \mathrm{~N} / \mathrm{mm}^{2}\left(f_{b, 0}=20 \mathrm{~N} / \mathrm{mm}^{2}\right)$ te morta srednje tlačne čvrstoće $f_{m}=5,1 \mathrm{~N} / \mathrm{mm}^{2}$. Nakon izvedbe uzorci su prekriveni polietilenskom folijom te tako čuvani do dana ispitivanja. Na licima uzoraka izveden je izravnavajući sloj mortom razreda M5. Tijekom ispitivanja opažani su pomaci u smjeru opterećenja (LVDT) na četiri mjesta, sila pri pojavi prve pukotine i sila sloma. Mort i elementi ziđa ispitani su nakon 28 dana starosti. Rezultati ispitivanja dani su u tablicama 6 i 7. Ispitni uzorak prikazan je na slici 3.

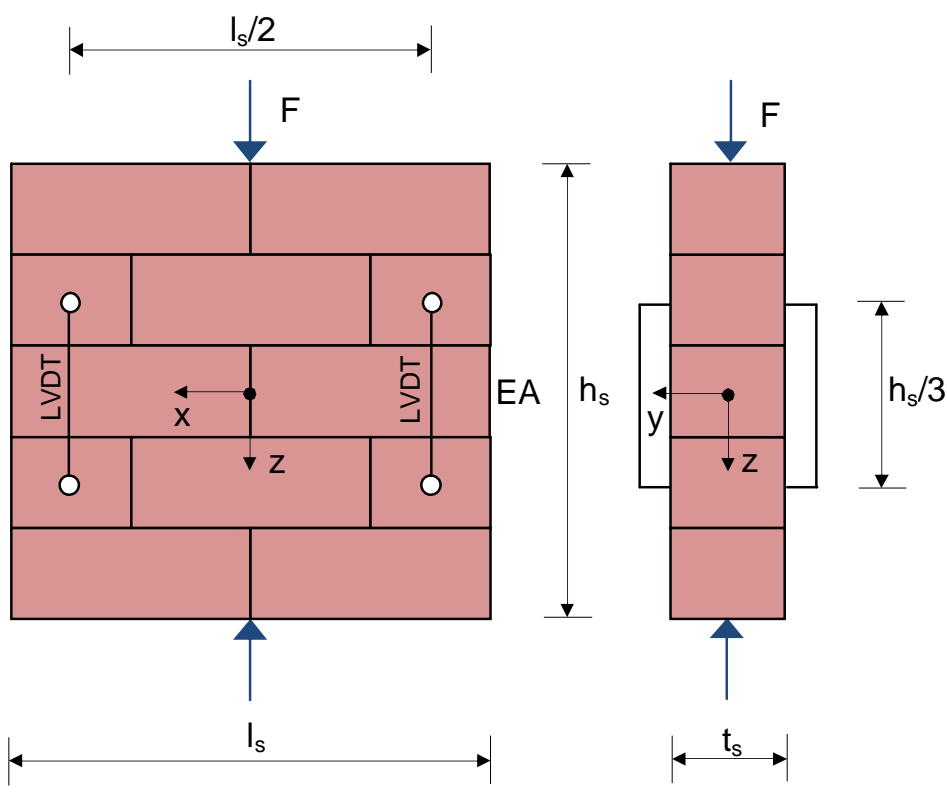

Slika 3 -Ispitni uzorak elementa ziđa

Tablica 6 - Rezultati ispitivanja tlačne čvrstoće nearmiranih elemenata ziđa

\begin{tabular}{|c|c|c|c|c|c|c|}
\hline $\begin{array}{l}\text { Redni broj uzorka } \\
\text { (n) }\end{array}$ & $\begin{array}{c}\text { Naprezanje pri pojavi } \\
\text { pukotina } \\
f_{c, c r}\left(\mathrm{~N} / \mathrm{mm}^{2}\right)\end{array}$ & $\begin{array}{l}\text { Tlačna čvrstoća } \\
\mathrm{f}_{\mathrm{cw}}\left(\mathrm{N} / \mathrm{mm}^{2}\right)\end{array}$ & $\begin{array}{c}\text { Srednja vrijednost } \\
\text { tlačne čvrstoće } \\
\mathrm{f}_{\mathrm{cw}, \mathrm{sr}}\left(\mathrm{N} / \mathrm{mm}^{2}\right)\end{array}$ & $\begin{array}{c}\text { Koeficijent } \\
\text { varijacije } \\
\mathrm{V}(\%)\end{array}$ & $\begin{array}{l}\text { Karc } \\
\text { tlačr } \\
\mathrm{f}_{\mathrm{cw}, \mathrm{w}}\end{array}$ & $\begin{array}{l}\text { istična } \\
\text { rstoća } \\
\mathrm{mm}^{2} \text { ) }\end{array}$ \\
\hline 1. & 4,2 & 4,9 & \multirow{3}{*}{3,8} & \multirow{3}{*}{26,4} & \multirow{3}{*}{3,10} & \multirow{3}{*}{3,13} \\
\hline 2. & 2,8 & 3,3 & & & & \\
\hline 3. & 2,6 & 3,1 & & & & \\
\hline
\end{tabular}

Prema podatcima danim u tablici 6, u skladu s normom HRN EN 1052-1:2004 [6], usvaja se karakteristična tlačna čvrstoća ziđa $f_{k}=f_{c w k, m i n}=3,10 \mathrm{~N} / \mathrm{mm}^{2}$, jer je $f_{c w k, \min }<f_{c w, s r} / 1,2$. 
Primjenom izraza

$$
E_{n}=\frac{F_{n, m x x}}{3 \varepsilon_{n} A_{n}}
$$

i podataka danih u tablici 7, određen je sekantni modul elastičnosti. Vrijednosti modula elastičnosti ziđa pojedinih elemenata ziđa, također su dani u tablici 7 . Srednja vrijednost sekantnog modula elastičnosti elemenata ziđa iznosi $E=1400 \mathrm{~N} / \mathrm{mm}^{2}$.

\section{Tablica 7 - Rezultati određivanja modula elastičnosti ziđa}

\begin{tabular}{|c|c|c|c|c|c|c|}
\hline $\begin{array}{l}\text { Redni broj } \\
\text { uzorka } \\
\text { (n) }\end{array}$ & $\begin{array}{l}\text { Sila sloma } \\
F_{n, \max }(k N)\end{array}$ & $\begin{array}{c}\text { Ploština uzorka } \\
A_{n}\left(\mathrm{~mm}^{2}\right)\end{array}$ & $\begin{array}{c}\text { Normalna deformacija } \\
\text { pri } 1 / 3 F_{n, \max } \\
\square_{n}(\%) \\
\end{array}$ & 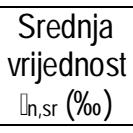 & $\begin{array}{l}\text { Modul elastičnosti } \\
\qquad E_{n}\left(\mathrm{~N} / \mathrm{mm}^{2}\right)\end{array}$ & $\begin{array}{c}\text { Srednja } \\
\text { vrijednost } \\
\mathrm{E}\left(\mathrm{N} / \mathrm{mm}^{2}\right) \\
\end{array}$ \\
\hline 1. & 300 & 61200 & 1,382 & \multirow{3}{*}{1,04} & 1182 & \multirow{3}{*}{1400} \\
\hline 2. & 200 & 61200 & 1,217 & & 895 & \\
\hline 3. & 190 & 61200 & 0,510 & & 2029 & \\
\hline
\end{tabular}

\subsection{Analitički pristup}

Ako vlastiti eksperimentalni podatci ispitivanja elemenata ziđa nisu dostupni, karakteristična tlačna čvrstoća ziđa određuje se primjenom analitičkog pristupa u skladu s normom prEN 1996-1-1 [2], na temelju podataka koje je objavio proizvođač.

Primjenom izraza

$$
f_{h}=K f_{b}^{a} f_{m}^{\beta}
$$

određuje se karakteristična tlačna čvrstoća ziđa, $f_{k}$. U gornjem je izrazu (3) $K=0,5$ konstanta ovisna 0 vrsti morta i grupi zidnog elementa, $\alpha=0,65$ i $\beta=0,25$ su konstante koje uzimaju u obzir razliciti doprinos zidnih elemenata i morta čvrstoći zida ovisno o vrsti morta, $f_{b}=19 \mathrm{~N} / \mathrm{mm}^{2}$ je normna srednja tlačna čvrstoća zidnog elementa, a $f_{m}=5,0 \mathrm{~N} / \mathrm{mm}^{2}$ tlačna čvrstoća morta. Primjenom navedenog izraza te usvojenih vrijednosti ulaznih parametara, karakteristična tlačna čvrstoća ziđa iznosi

$$
f_{h}=0,5 \cdot 1,9,0^{0,65} \cdot 5,0^{0.25}=5,2 \mathrm{Nmm}^{2}
$$

Usvajanjem vlastitih eksperimentalnih podataka o tlačnoj čvrstoći zidnih elemenata $f_{b}=40,0 \mathrm{~N} / \mathrm{mm}^{2}$, te morta $f_{m}=5,1$ $\mathrm{N} / \mathrm{mm}^{2}$, dobije se vrijednost karakteristične tlačne čvrstoće ziđa

$$
f_{k}=0,5 \cdot 40,0^{0.65} \cdot 5,1^{0,25}=8,3 \mathrm{~N} / \mathrm{mm}^{2}
$$


Razlika između vrijednosti karakteristične tlačne čvrstoće iz izraza (4) i (5) proizlazi iz različitih vrijednosti normalizirane čvrstoće zidnog elementa dobivenih vlastitim ispitivanjima i objavljenih od strane proizvođača.

U normi prEN 1996-1-1 [2] nisu navedeni matematički izrazi za približno određivanje sekantnog modula elastičnosti pa se on mora odrediti ispitivanjem u skladu s normom HRN EN 1052-1:2004 [5]. Preporuka iz [8], kao npr. izraz

$$
E=1000 \cdot f_{k}
$$

daje približne vrijednosti. U tablici 8 prikazani su rezultati proračuna i uspredba modula elatičnosti dobivenih analitičkim izrazom, te eksperimentalnim putem.

\section{Tablica 8 - Proračun i usporedba modula elastičnosti}

\begin{tabular}{|c|c|c|}
\hline $\begin{array}{c}\text { Karakteristična tlačna } \\
\text { čvrstoća ziđa } \\
f_{\mathrm{k}}\left(\mathrm{N} / \mathrm{mm}^{2}\right)\end{array}$ & $\begin{array}{c}\text { Modul elastičnosti iz analitičkog } \\
\text { izraza } \mathrm{E}=1000 \cdot \mathrm{f}_{\mathrm{k}} \\
\left(\mathrm{N} / \mathrm{mm}^{2}\right)\end{array}$ & $\begin{array}{c}\text { Odstupanje od eksperimentalne } \\
\text { vrijednosti } \mathrm{E}=1400 \mathrm{~N} / \mathrm{mm}^{2} \\
(\%)\end{array}$ \\
\hline 5,2 & 5200 & 73 \\
\hline 8,3 & 8300 & 83 \\
\hline 3,1 & 3100 & 55 \\
\hline
\end{tabular}

\section{Posmična čvrstoća ziđa}

Posmična čvrstoća ziđa ovisi o kutu unutarnjeg trenja te početnoj posmičnoj čvrstoći. Prema normi prEN 1996-1-1 [2], njihove vrijednosti je potrebno odrediti ispitivanjem. S ciljem određivanja karakteristične početne posmične čvrstoće ziđa $f_{v k o}$ i karakterističnog kuta unutarnjeg trenja $\tan \phi_{k}$ u skladu s normom HRN EN 1052-3:2004 [7], pripremljeno je ukupno 9 uzoraka izvedenih od po tri pune opeke. Uzorci su neposredno nakon izvedbe bili ravnomjerno opterećeni s $2 \cdot 10^{-3} \mathrm{~N} / \mathrm{mm}^{2}$, te su prekriveni polietilenskom folijom. Tijekom ispitivanja, opažane su najveća posmična sila $F_{n, \max }$ normalna sila $F_{n, p}$, te način sloma. Ispitivanje je provedeno 28 dana nakon izvedbe, u serijama po 3 uzorka s pripadnim normalnim naprezanjem $0,2 \mathrm{~N} / \mathrm{mm}^{2}, 0,6 \mathrm{~N} / \mathrm{mm}^{2}$ te $1,0 \mathrm{~N} / \mathrm{mm}^{2}$. Slom se događao na kontaktu morta i zidnog elementa. Način ispitivanja vidi se na slici 4.

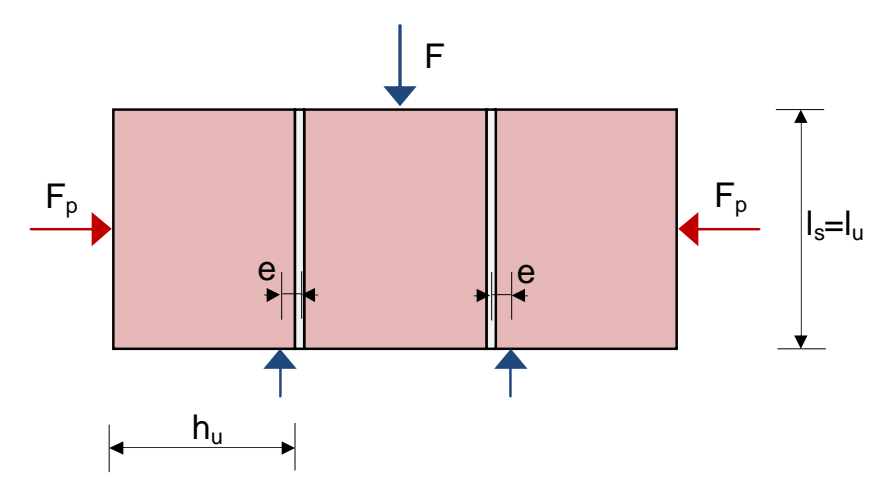

Slika 4 - Opterećenje uzorka pri ispitivanju na posmik 
Srednje vrijednosti posmične čvrstoće, dobivene ispitivanjem na uzorcima s tri različite vrijednosti normalnih naprezanja, prikazane su na dijagramu na slici 5. Linearnom ekstrapolacijom na danom dijagramu dobije se srednja vrijednost početne posmične čvrstoće koja iznosi $f_{v 0}=0,35 \mathrm{~N} / \mathrm{mm}^{2}$. Određena je srednja vrijednost kuta unutarnjeg trenja $\tan \phi=0,71$. Karakteristične vrijednosti u skladu s normom HRN EN 1052-3:2004 [7] dobiju se množenjem srednjih vrijednosti faktorom 0,8 , tj.

$$
f_{v h 0}=0,8 f_{v 0}=0,28 \mathrm{Nmm}^{2}
$$

i

$$
\tan \Phi_{k}=0,8 \cdot \tan \Phi=0,57
$$

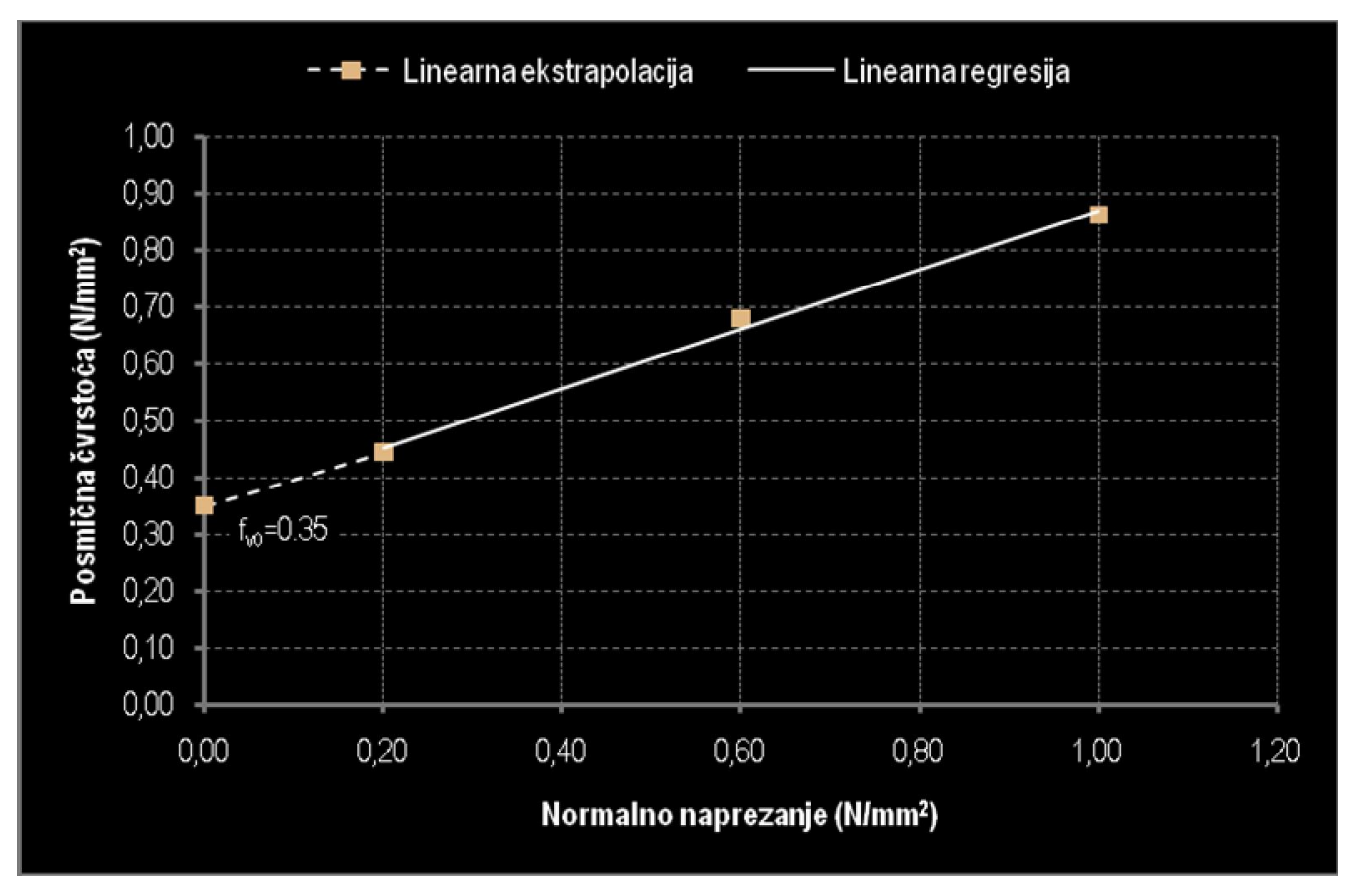

Slika 5 - Srednje vrijednosti posmične čvrstoće pri različitim normalnim naprezanjima

\section{$6 \quad$ Zaključak}

Ispitivanje zidnih elemenata provedeno je u skladu s normama HRN EN 771-1:2002 [3] i HRN EN 772-1:2004 [4], ispitivanje morta u skladu s normom HRN EN 1015-11:2000 [5] te ispitivanje tlačne i posmične čvrstoće ziđa u skladu s normama HRN EN 1052-1:2004 [6] i HRN EN 1052-2:2004 [7].

U skladu s normom HRN EN 771-1:2002 [3] uzorcima pune opeke utvrđene su stvarne izmjere te je, usporedbom s radnim izmjerama koje je objavio proizvođač, utvrđeno da zidni elementi imaju odstupanja u visini elementa pa ne pripadaju razredu T1 niti razredu T2. Ispitivanjem uzoraka pune opeke u skladu s normom HRN EN 772-1:2004 [4], dobivena tlačna čvrstoća dvostruko je veća od vrijednosti koju je objavio proizvođač.

Vrijednost tlačne čvrstoće ziđa dobivene ispitivanjima u skladu s normom HRN EN 1052-1:2004 [6], do 60\% je niža od vrijednosti dobivenih analitičkim izrazima. Kod sekantnog modula elastičnosti, usporedbom vrijednosti 
dobivenih analitički i eksperimentalno, utvrđeno je odstupanje u vrijednostima do $80 \%$, najniža vrijednost dobivena je eksperimentalnim putem.

U skladu s normom HRN EN 1052-2:2004 [7], određena karakteristična početna posmična čvrstoća $f_{v k 0}=0,28$ $\mathrm{N} / \mathrm{mm}^{2}$ veća je od vrijednosti $f_{v k 0}=0,1 \mathrm{~N} / \mathrm{mm}^{2}$ koja je preporučena normom prEN 1996-1-1 [2] u slučaju nedostatka eksperimentalnih podataka, te je stoga navedena vrijednost na strani sigurnosti. Karakteristična vrijednost kuta unutarnjeg trenja u skladu s normom prEN 1996-1-1 [2] iznosi 0,4, dok je ispitivanjima utvrđena vrijednost 0,6, čime je vrijednost 0,4 u ovom slučaju također na strani sigurnosti.

\section{Literatura}

[1] Mirosavljević, K., Određivanje mehaničkih svojstava ziđa od pune opeke zidanog mortom M5, diplomski rad, Građevinski fakultet Sveučilišta J.J. Strossmayera u Osijeku, Osijek, 2009.

[2] prEN 1996-1-1, Design of masonry structures, Part 1-1: Common rules for reinforced and unreinforced masonry structures, European Committee for Standardization, CEN, Brussels, 2004.

[3] HRN EN 771-1:2002, Specifikacije za zidne elemente - 1. dio: Opečni zidni elementi (prEN 771-1)

[4] HRN EN 772-2:2004, Metode ispitivanja zidnih elemenata - 1. dio: Određivanje tlačne čvrstoće (EN 772-1:2004)

[5] HRN EN 1015-11:2000, Metode ispitivanja mortova za ziđe - 11. dio: Određivanje čvrstoće pri savijanju i tlačne čvrstoće očvrslog morta (EN 1015-11:1999)

[6] HRN EN 1052-1:2004, Metode ispitivanja ziđa - 1. dio: Određivanje tlačne čvrstoće (EN 1052-1:1998)

[7] HRN EN 1052-3:2004, Metode ispitivanja ziđa - 3. dio: Određivanje početne posmične čvrstoće (prEN 10523:2001)

[8] Sorić, Z., Zidane konstrukcije I, 2.izd., vlast. nakl., Zagreb, 2004. 